УДК $811.111 .2 ’ 25(=161.1)$

\title{
The Influence of the Sociolect Nature \\ of the Text on the Choice \\ of Translation Strategy
}

\author{
Elena V. Kharitonova* \\ North-Eastern State University \\ 13 Portovaya Str., Magadan, 685000, Russia
}

Received 15.11.2016, received in revised form 01.12.2016, accepted 06.02.2017

Selecting the appropriate translation strategy during the process of translation has always been one of the key issues of translation theory. Different aspects influencing the choice of the translation strategy have often been discussed. These are the general properties of the text (the type of the text, its pragmatic features, the register, etc.), linguistic personality of the author, intentions of a translator, peculiarities of the recipient audience. In the paper an attempt is made to approach translation strategy from the point of the sociolect nature of the text, correct understanding and transmission of which becomes one of the primary tasks in the process of the translation of the text from the source language to the target language. The original Russian text of "One Day in the Life of Ivan Denisovich" by A. Solzhenitsyn and its translations into English, performed by T. Whitney and G. Aitken, as well as the novel by T. R. Smith "The Secret Speech" are the research material of this article. This article presents the results of the research showing the benefits of the strategy of functional substitution in terms of the translating of sociolect texts.

Keywords: translation strategy, sociolect text, the strategy of functional substitution.

DOI: 10.17516/1997-1370-0056.

Research area: philology.

\section{Introduction}

Recent theoretical developments in literary translation introduced the notions of original inexhaustibility and translation multiplicity (Chaykovskiy, Lysenkova, 2001: 188-198), which now are viewed as integral components of the categorical paradigm of literary translation. Studying the translations of the same original in the context of translation multiplicity shows that foreign versions of the original text can have significant differences. Experts in the field of literary translation point out various reasons for translation multiplicity, among which the crucial role belongs to translation strategies and tactics used by the translators in the process of their search for the optimal translation equivalent. Translation strategy is predetermined by many factors, such as the following: the personal attitude of the translator, the aim of the translation, and the peculiarities of the communicative situation in which the translation is performed. Rightly chosen translation strategy, in its turn, in

(c) Siberian Federal University. All rights reserved

* Corresponding author E-mail address: eharitonova@yandex.ru 
many respects determines the efficiency of the following translation operations.

\section{Translation of Texts: from Culture-Sympathy to Cultural Bumps}

A good choice of the means of translation of a foreign culture made by the translator can lead to the "cross-cultural assimilation" of the translated text, when the culture specific for the source language is "imported" to the culture of the target language (on the possibility of import of the foreign culture, see: (Prunch, 2015: 366)). In addition to this, E. Maslennikova points out the fact that integrated cultures can be assimilated when the source-culture ("donor-culture" in the scholar's terms) or its separate elements enter the foreign culture, simultaneously enriching the recipient culture. In such a case culture assimilation presupposes fusion or merging of cultures as culture-sympathy (Maslennikova, 2014: 152).

However, the possibility of cross-cultural assimilation will not always depend on the nature of the translator's decisions. In some cases, as E. Maslennikova rightly states, cultures, on the contrary, can oppose each other, which leads to cultural bumps or clashes, resulting when the original and its translation, embodying two alien cultural worlds, come up against each other as "opposing" or even "mutually exclusive" (Ibid.: 152, 156). In this case the possibility of the import of the foreign culture to the target culture is significantly limited, thus reducing the degree of text translatability. M. SnellHornby, in this respect, gave sufficient evidence that the possibility of the translation of the original text greatly depends on the degree of its cultural specificity: "the extent to which a text is translatable varies with the degree to which it is embedded in its own specific culture, also with the distance that separates the cultural background of source text and target audience in terms of time and place" (Snell-Hornby, 1988: 41).

\section{On the Notion of Sociolect Text}

The above said to the full extent refers to the translation of the sociolect texts. The term "sociolect text" is understood as a form of communication used by an author to transmit the specificity of a described culture, or a subculture by means of accumulating language means characteristic for this or that social group. The language of a literary text, as a rule, cannot be identified with the natural language; it becomes a social dialect, a 'sociolect' revealing a particular structure of a certain culture or a subculture. The notion of a sociolect implies the employment of non-standard lexical and phraseological means of expression and single deviations from the norm in the spheres of grammar and phonetics. Moreover, a social dialect may serve as an antilanguage a term coined by M. A. K. Halliday and further elaborated by B. McHale in his Postmodernist Fiction. The author writes: "An antilanguage is the specialized discourse of a deviant social group - either deviant in the usual negative sense (e.g. criminal and prison subcultures) or what we might call prestigiously deviant (e.g. military elites, religious mystics, perhaps even poets). Just as the group's behavior deviates from social norms, so analogously its language deviates from the standard"(McHale, 2004: 168). Thus, sociolect texts are also viewed as a form of communication, possessing a number of strongly marked ethnic integrating and differentiating features. Marked by a high degree of cultural specificity, units of sociolect texts do not only reflect peculiarities of the subculture within which they came into being on the referential level, representing culturallymarked aspects of physical and social worlds, but also transmit a unique system of cultural values, reflecting the psychology and ideology of this or that social stratum. The social and cultural load 
of the sociolect text makes it not only the means of communication between the sender and the addressee, but also the bearer of a unique cultural code, understanding and transmission of which becomes one of the primary tasks in the process of translation of the text from the source language (SL) to the target language (TL).

\section{Theoretical Framework}

The sociolect nature of the original text does influence, and in some cases even predetermines the choice of translation strategy. Coming back to translation strategies, it is important to mention that the definition, as well as the interpretation of this notion is rather vague. Having analyzed numerous researches devoted to translation strategies, V. Sdobnikov came to the conclusion that the notion of translation strategy is one of the most ambiguous in contemporary translation studies (Sdobnikov, 2015: 130). Indeed, the multiple meanings of this term found in the text books and articles on translation studies have lead to unjustified equating of such notions as translation strategies, translation tactics and translation operations. For instance, E. Maslennikova summarizes existing translation strategies in the following way: strategies of foreignization and domestication (Voynich, 2010; Venuti, 1995; et al.), strategy of finding 'the golden middle' (Voynich, 2010), strategy of 'estrangement' (Kornaukhova, 2011), strategies of archaization and modernization, convergence strategy (Kharitonova, 2010), and the strategy of neutralization of literary translation(Maslennikova, 2014: 157-208). Giving the author her due for the detailed and elaborate description of different approaches to the problem of translation strategies, nevertheless, we cannot completely agree that all of the enumerated cases should be referred to as translation strategies.

Convergence in translation should be viewed not as an independent translation strategy, but rather as a translation device aimed at creating a certain hyperonym accumulating in itself several meanings, which may be quite different. This translation device simplifies greatly the process of finding a suitable translation equivalent for culture-specific concepts and terms, on one hand, and makes it easier to perceive a new reality embedded into the foreign text by the recipient of the translation, on the other. The evident drawback of this translation method is that it is unable to render overlexicalization, which is so typical for a sociolect text. Under the term "overlexicalization" B. McHale understands "proliferation of synonyms or near-synonyms for concepts especially important to the group" (McHale, 2004: 168). For example, if to compare two English translations of One Day in the Life of Ivan Denisovich performed by T. P. Whitney (1963) and G. Aitken (1971) the difference in translation approaches will be quite significant. G. Aitken used the method of translation convergence in translating various designations of camp reality into English. For instance, the translator converged more than ten designations of different types of Soviet camp guards (vakhter, dezhurnyak, konvoir, knovoy, nadziratel, nachkar, naryadchik, karaul, okhrana, popka, chasovoy) in a single word 'guards'. On the contrary, T. Whitney found an equivalent almost for each of the terms: (vakhter - sentry, dezhurnyak - <->, konvoir - convoy/sergeant, knovoy - guard(s), nadziratel - warder, nachkar commander, naryadchik - work-assigner, karaul - escort, okhrana - guards, popka - poll-parrot, chasovoy - sentry). The second approach seems to us more appropriate as it approximates the original transmitting a highly complicated system of camp guard.

Neutralization, it seems to us, should not be considered as a translation strategy at all. Neutralization of the cultural specificity of the original text is not a strategy, but a result of the 
work of the translator who did not cope with the rendering of culture-bound elements into the target language, due to which many of the textual connotative meanings (emotive, evaluative, expressive, etc.) become lost in the translation process.

As for estrangement as a translation strategy, it leads to the creation of a certain "imaging" of the original. The term "estrangement" ("ostranenie" in Rusian), put forward by V. B. Shklovskiy for the literature theory means the creation of a special "perception" or "viewing" of an object, which leads not to familiarization with the object, but to its subjective projection in the mind of the recipient (Shklovskiy, 1983: 20). This device helps to concentrate the reader's attention on the object, to perceive it sensually rather than rationally and thus to apprehend its uniqueness. The term "estrangement" has been successfully adopted by other branches of humanitarian knowledge, including translation theory. The weak point of estrangement as a translation theory is that it is possible only when the author of the original, himself proposes its existence in the text. As Yu. E. Valkova has reasonably put it, "the translation of ST should have the adequate proportion of estranging effect" (Valkova, 2015: 2823). The author further puts forth the question "Is the addition of the estranging effect, not thoughtof by the author, always bad for the translated text?" That is a disputable point, as it is clearly seen from the discussion provided in Valkova's article. It may seem that estrangement, applied as a translation theory, can really bring forward additional meanings, thus enhancing the intention of the original text. However, we strongly doubt that this will benefit the translation. In this case we are also faced with a specific adaptation of the original text, only this time not to meet the expectations of the reader, but in accordance with the point of view of a translator, who is co-authoring with the author. Meanwhile, the discussion on the point of the translator's right for his own creativity is still one of the most disputable in contemporary translation studies. Moreover, we also think that it is wrong to believe that the abundant use of culture-bound words in the source text means that the author sought after the estranging effect. Culture-bound words are not perceived as strange, alien or weird by the members of the society within which they came into being. In this case quite often the translators have to deal not with estrangement, but with the problem familiarization of the target audience with these "ignotisms". Here the task of the translator, as it was formulated by V. Razumovskaya in her article "Estranging Strategy in Translation of "Strong" Texts of the Russian Culture", is first of all to identify correctly and precisely the cases of estrangement manifested in the original, and only then to look for the way to preserve the estrangement device in translation, applying the strategy of translating estrangement (Razumovskaya, 2014: 189).

In our opinion, the definition of the translation strategy worked out by V. Sdobnikov based on the communicative-functional approach to translation makes it possible not only to avoid terminological inconsistence, but also contributes to facilitating the translator's deliberate elaboration of a certain policy or line of conduct in accordance with the final aim of the translation. The author states that translation strategy - is a general program of conducting translation activity under the conditions of a certain communicative situation of bilingual intercourse, which is determined by specific features of this situation, as well as by the translation aims, and which, in its turn, determines the nature of the professional conduct of the translator within the frames of this communicative situation (Sdobnikov, 2105: 215-216). In the next part of our article we will demonstrate the possibility of practical appliance of the suggested program of conducting translation 
activity using the example of translations of camp sociolect texts in which the authors deliberately accumulated the vocabulary specific for Soviet camp social dialect.

\section{Sociolect Text and Translation Strategy}

When one is faced with the problem of the translation of camp sociolect texts, traditional translation strategies, such as foreignization and domestication quite often turn out to be insufficient. Domestication aimed at benefiting the target language audience, making the text readable and understandable for them by leaving out those elements of the original which may seem strange, alien or otherwise not conforming conventions of the target culture or target language, inevitably leads to a certain distortion of the original. Moreover, domestication of the sociolect text will not only result in an undesirable substitution of the source language national communicative style by the communicative style of the foreign recipient, but also will lead to the loss of the sociolect nature of the text, which can be equal to communicative failure. Besides, domestication of the camp sociolect text can often turn out to be absolutely inefficient, as it is unable to compensate cognitive dissonance experienced by western readers when they first read Soviet camp prose in English. The story of screening in the west of the well-known play by A. Solzhenitsyn "One Day of Ivan Denisovich" can serve as a good example of such a cognitive failure. The first attempts to shoot a film based on Solzhenitsyn's work found no support among the producers who summed up their opinion as follows: "Lots of snow. Lots of long Russian names. No women. No escapes. No violence. Would have to be "opened up"... Recommendation: Not for us" (Harwood, 1971: 1).

Foreignization of camp sociolect texts, in its turn, on one hand, can lead to problems of understanding, as its primary aim is to remind the target reader that the text he reads is not the original and he deals with a new culture, and characteristics of a different language. On the other hand, it can result in unnecessary exotization of the translation. For example, a wellknown novel by T. R. Smith "The Secret Speech" was overloaded with camp speech (ex.: Not only is she vory, she's a leader. She no longer goes by the name Anisya. Her klikukha is Fraera (Smith, 2010: 214)). The author used numerous cases of transliteration of Russian camp terms, and it becomes clear that his main intention was to create a special mood, to add a specific flavor to his story, to make it sound exotic, unusual and even weird in order to stir his readers' curiosity.

As it is well known, the roots of foreignization and domestication can be traced back to the German philosopher F. Schleiermacher's argument that there are only two different methods of translation: "either the translator leaves the author in peace, as much as possible, and moves the reader towards him; or he leaves the reader in peace, as much as possible, and moves the author towards him" (Schleiermacher, 2000: 132-133). Today the statement about the uniqueness of these two strategies is a subject of much controversy. Some scholars believe that the best way is to choose one of the strategies and stick to it, rather than to tear around both of them. For example, M. Gasparov in his article Briusov and Word for Word Translation raises a question if it is really wise to require the translator to look for the "unachievable golden middle" between the two approaches to translation (Gasparov, 1988). On the other hand, others suggest a different translation strategy, aiming at creating a hybrid text: "The choice of cultural strategy may result in source-culture bound translation (the translation stays within the SL culture), target-culture bound translation (the translation stays within the TL culture) or in a hybrid, where the translation is a product 
of a compromise between two or more cultures" (Schäffner, 1997: 329). In the works of Russian scholars this approach is known as a search for the 'golden middle'. The essence of this strategy is in finding the right balance between what a translator must say (being guided by the original: foreignization), what a translator can say (being guided by the target language - domestication), and finally, what a translator wants to say (being guided by his own preferences and tastes) (Voinich, 2010: 43).

In our opinion, such an approach can be rather risky. Creation of a hybrid brings simultaneous coexistence inside of one text of the source-culture and of the target-culture elements. And if the presence of the former is obligatory for any translation of the culture specific text, how to explain the presence of the later in the text originally meant for a different audience? When the author intends to write a novel he does so bearing in mind particular objectives and having deeply studied the psychology of his audience, formed by a specific ethnic and social culture. A hybrid or any blending of the source-culture with the target-culture will inevitably lead to a significant distortion of the original text, which is being made 'to serve' two masters at the same time. Thus, the other side of the compromise, which at first sounds quite reasonable, may be cultural marginalization of the translation, associated with neither the source nor the target culture. We cannot deny the fact that translation implies not only the interaction of two different languages, but of two different cultures, but this interaction, as it seems to us, should be realized not by adapting, but by adopting, not by compromising, but by enriching the target culture with source-culture specific elements. The translator should display the greatest zeal in trying to preserve the features of the original, because if he fails to do so, it will diminish the merit of the author's work.
Coming back to the problem of translation of camp sociolect texts, we have to admit that neither foreignization nor domestication seem to work well enough to serve as a translation strategy for this type of sociolect texts. To work out an applicable translation strategy we suggest to have a closer look at the interpretation of the term 'strategy of translation' given by V. Sdobnikov. According to the scholar one of the major and foremost characteristics of communicative situation via translation is the purpose of the translation, which is determined, in its turn, by the conditions of communicators' activity. As we have already written above, one of the primary tasks in the process of translation of sociolect texts is the transmission of its sociolect nature, which is perceived as a kind of a 'language passport' for the bearers of this sociolect. To avoid the loss of the sociolect nature of the text one should rely on the strategy of functional substitution based on the functional intention of the text. We used the term «substitution» not to be confused with the Functional Equivalence Theory put forward by E. Nida, according to whom "the relationship of the target language receptors to the target language text should be roughly equivalent to the relationship between the original receptors and the original text" (Nida, 1978: 119). As it is well known, Nida focuses on the equivalence of the receptors' response rather than the equivalence of language forms, thus the rendering of the foreign text implies some degree of domestication in order to adopt the culture patterns familiar to the target audience.

Nida'stheory, as wellas domesticationstrategy, centres around the reaction of the recipient, while we suggest shifting the focus towards the text. Cognitive units of a sociolect text serve not only as a form of coding and storing of the information, but also as a means of intra-group identification. It is important to underline the fact that sociolect units do not always belong to non-equivalent words. 
Due to such lexical processes as relexicalizationthe term suggested by B. McHale, under which the scholar means "adaptation of a standard word to special, nonstandard use within the group" (McHale, 2004: 168) and overlexicalization standard means of expression in sociolect environment acquire additional meanings, which makes it impossible to use their equivalents in other languages. The units of a sociolect dialect can be defined as 'hotspots/rich points', which are found in the communication of any more or less isolated communities. The term 'hotspots/rich points' suggested by American linguist M. Agar, denotes those elements of the discourse which are loaded with the features, specific for a certain culture or subculture: "some things that come up strike you with their difficulty, their complexity, their inability to fit into the resources you use to make sense out of the world. These things - from lexical items through speech act up to extensive stretches of discourse - are called rich points ... Rich points are rich because of the intricate web of associations and connotations that they carry with them, webs that have no corresponding echoes in your own language. Rich points ... are the linguistic tip of the cultural iceberg, the locations in discourse where major cultural differences are signaled" (Agar, 1994: 231). Depriving the target text of those elements by way of text adaptation can hardly be justified, as this only hypertrophies cultural and ethnical differences between peoples and underestimates the ability of a reader to adopt the elements of an alien culture and to understand that other people can have different traditions or living conditions. On the other hand, the excessive importing of these hotspots into the target language, and through it into the target culture, is not always necessary either, as such quasi-signals of cultural specificity hinder the understanding of the text and lead to adding extra exotic character to the target text. Camp sociolect text must be rendered as socially-marked text, inseparably connected with the social stratum which predetermined its coming into being and this idea must be the starting point of the strategy of its translation into a target language.

\section{Conclusion}

Camp sociolect cannot be described in terms of criminal jargon or argot, as it served as a specific antilanguage, developed as the result of the systematic transformations of the standard language and opposed to the 'official' standard language outside the camp boundaries. The translation strategy of rendering camp sociolect texts must be worked out by taking into account its 'antifree-world-view' intention, as well as such lexical phenomena as relexicalization, overlexicalization, priority of significative meaning over denotative, terminological character of its naming means, tendency to brevity, etc. The strategy of functional substitution aimed at transmitting functional intention of the text may serve as a more or less objective guideline to the translator of a sociolect text. Moreover, it makes it possible to leave aside the argument whether a translation should be read as a "domesticated" (Latyshev, 2004: 198) or "otherworldly" (Sdobnikov, Petrova, 2006: 400), as in this case translations will be read as translations, as texts in their own right.

\section{References}

Agar, M. (1994). The intercultural frame, In International Journal of Intercultural Relations, 18 (2), 221-237.

Chaykovskiy, R.R., Lysenkova, E.L. (2001). Neischerpayemost' originala. 100 perevodov "Pantery" R.M. Ril'ke na 15 iazykov [The Inexhaustible Original: 100 Translations of "Panther" by R.M. Rilke into 15 Languages]. Magadan, Kordis, 211 p. 
Gasparov, M.L. (1988). Briusov i bukvalizm [Briusov and word for word translation], In Poetika perevoda [Poetics of translation], available at: http://philology.ru/linguistics1/gasparov-88.htm (accessed 5 July 2016).

Harwood, R. (1971). Introduction, In The Making of One Day in the Life of Ivan Denisovich by A. I. Solzhenitsyn, 1-24.

Kharitonova, E.V. (2010). Dialektika perevodcheskikh strategii: perevodnaia dispersiia vs perevodnaia konvergentsyia [Dialectics of translation strategies: translation dispersion vs translation convergence], In Vestnik Voronezhskogo gosudarstvennogo universiteta. Seriia: Lingvistika $i$ mezhkulturnaia kommunikatsyia [Voronezh State University Bulletin. Series: Linguistics and intercultural communication]. 2, 196-199.

Latyshev, L.K. (2004). K probleme opedeleniia lingvokulturnogo aspekta perevoda [To the problem of defining linguocultural aspect of translation]. Materialy mezhvuzovskoi nauchnoi konferentsii "Mezhkulturnaia kommunikatsiia i perevod" [Proceedings of inter-university scientific conference]. Moscow, 195-199.

Maslennikova, E.M. (2014). Khudozhestvennyi perevod: novoe o starom [Literary translation: new about the old]. Tver, Tverskoi gosudarstvennyi universitet, $240 \mathrm{p}$.

McHale, B. (2004). Postmodernist Fiction. London and New York, Taylor \& Francis Group, $264 \mathrm{p}$.

Nida, E. K nauke perevodit‘. Printsypy sootvetstvii [Towards a Science of Translating. Principles of correspondence], In Voprosy teorii perevoda v zarubezhnoi lingvistike [The Issues of translation theory in foreign linguistics], Moscow, Mezhdunarodnye otnosheniia, 114-137.

Prunch, E. (2015). Puti razvitiia zapadnogo perevodovedeniia. Ot iazykovoi assimetrii $k$ politicheskoi [The ways of development of eastern theory of translation. From language asymmetry to political]. - Moscow, Valent, $512 \mathrm{p}$.

Razumovskaya, V. (2014). Strategiia ostraneniia v perevode "sil'nykh" tekstov russkoi kultury [Estranging Strategy in Translation of "Strong" Texts of the Russian Culture], In Mundo Eslavo, 13, 177-192, available at: http://mundoeslavo.com/index.php/meslav/article/view/180/160 (accessed 15 July 2016).

Schäffner, C., Adab, B. (1997). Translation as Intercultural Communication - Contact as Conflict, In Translation as Intercultural Communication. Selected Papers from the First Congress, 325-337.

Schleiermacher, F. (2000). O raznykh metodakh perevoda [On different methods of translation], In Vestnik Moskovskogo universiteta. Seriia 9. Filologiia [Moscow State University Bulletin. Series 9. Philology]. 2, 127-145.

Sdobnikov, V.V. (2015). Kommunikativnaia situatsiia kak osnova vybora strategii perevoda: diss... dok. filol. nauk [Communicative situation as the basis for choosing translation strategy: diss. ... Doctor of Philology]. Nizhni Novgorod, $492 \mathrm{p}$.

Sdobnikov, V.V., Petrova, O.V. (2006). Teoriia perevoda (uchebnik dlia studentov lingvisticheskikh vuzov i fakultetov inostrannykh iazykov) [Theory of translation (a textbook for students of linguistics and foreign languages)]. Moscow, AST: Vostok-Zapad, $448 \mathrm{p}$.

Shklovskiy, V. (1983). Iskusstvo kak priem [Art as a method], In O teorii prozy [On theory of prose]. Moscow, Sovetskii pisatel, 9-26.

Smith, T.R. (2010). The Secret Speech. London; Sydney; New York; Toronto, Pocket Books, 449 p. 
Snell-Hornby, M. (1988). Translation Studies. An Integrated Approach. Amsterdam, J. Benjamins, $163 \mathrm{p}$.

Solzhenitsyn, A. (1963). One Day in the Life of Ivan Denisovich: translated by Thomas P. Whitney. N. Y., Fawcett, 160 p.

Solzhenitsyn, A. (1971). One Day in the Life of Ivan Denisovich: translated by Gillon Aitken. N. Y., Ballantine Books, 271 p.

Valkova, Yu.E. (2015). On Theoretical Aspects of Translating Estrangement, In Journal of Siberian Federal University. Humanities \& Social Sciences, 12 (2015 8), 2821-2832, available at: http:// elib.sfu-kras.ru/bitstream/handle/2311/19969/03_Valkova.pdf?sequence=1\&isAllowed=y (accessed 15 July 2016).

Voinich, I.V. (2010). "Zolotaia seredina" kak strategiia perevoda: o (ne)vozmozhnosti ee dostizheniia ["Golden middle" as a translation strategy: on the (im)possibility of its achieving], In Mir nauki, kultury, obrazovaniia [The world of science, culture, education]. 1(20), 41-45.

\title{
Влияние социолектной природы текста на выбор переводческой стратегии
}

\author{
Е.В. Харитонова \\ Северо-Восточный государственный университет \\ Россия, 685000, Магадан, ул. Портовая, 13
}

Проблема выбора верной переводческой стратегии в проиессе перевода всегда являлась одной из иентральных в практике и теории художественного перевода. В работах исследователей неоднократно рассматривались те или иные аспекты, оказывающие влияние на выбор переводческой стратегии, в том числе характеристики переводимого текста (тип текста, его прагматические особенности, регистр и др.), языковая личность автора, установка переводчика, особенности получателей перевода. В статье предпринята попытка проанализировать характер переводческой стратегии с точки зрения сочиолектной природы текста, верное понимание и передача которой является одной из главных задач переводчика. Материалом исследования послужили оригинал произведения А. И. Солженицына «Один день Ивана Денисовича», его англоязычные переводы, выполненные Т. Уитни и Г. Айткеном, а также роман Т. Р. Смита «The Secret Speеch». В статье представлены результаты исследования, демонстрирующие преимущества стратегии функиионального аналога при переводе соииолектных текстов.

Ключевые слова: стратегия перевода, тактика перевода, сочиолектный текст.

Научная спеииальность: 10.00.00 - филологические науки. 